\title{
WRITING LITERACY AS AN EFFORT TO BUILD POSITIVE CHARACTER OF ELEMENTARY SCHOOL STUDENTS
}

\author{
Chandra $^{1}$, Darnis Arief ${ }^{1}$, Annisa Kharisma ${ }^{1}$, M. Habibi ${ }^{1}$, Ari Suriani ${ }^{1}$ \\ ${ }^{1}$ Primary School Teacher Education Department, Universitas Negeri Padang, Indonesia \\ chandra@fip.unp.ac.id, darnisariefunp@gmail.com, annisakharisma92@gmail.com, habibie74@gmail.com
}

\begin{abstract}
The purposes of the study were to analyze the profile of the development of literacy teaching materials in writing prose and produce prototypes of teaching materials for students' prose writing which included the development of positive characters written by elementary school children. Writing habits with the planting of characters familiarize students to be positive following what is usually done. This is based on the character of students currently still concerning. The model of developing prose literacy for elementary students used is the Plomp model with steps: preliminary research, prototyping phase, and assessment phase. Participants in this study, namely experts, elementary students, and elementary school teachers. Data obtained by triangulating data and analyzed by processing quantitative descriptive data. The research findings indicate that the characteristic profile of students tends to be difficult in writing prose essays. The profile of needs analysis shows that elementary students are very fond of fantasy fairy tales, fables, parables, myths, realistic tales, and sage. The prototype of literacy teaching materials writes valid prose according to the needs of students.
\end{abstract}

Keywords: positive characters, writing literacy, elementary school.

\section{LITERASI MENULIS SEBAGAI UPAYA UNTUK MEMBANGUN KARAKTER POSITIF SISWA SEKOLAH DASAR}

\begin{abstract}
ABSTRAK
Tujuan penelitian menganalisis profil pengembangan bahan ajar literasi menulis prosa dan menghasilkan prototipe bahan ajar karya tulis prosa siswa yang memuat pembangunan karakter positif yang ditulis oleh anak SD. Kebiasaan menulis dengan adanya penanaman karakter membiasakan siswa untuk bersikap positif sesuai dengan yang biasa dilakukan. Hal ini dilandaskan pada karakter siswa saat ini masih memprihatinkan. Model pengembangan literasi menulis prosa untuk siswa SD yang digunakan yaitu model Plomp dengan langkah: preliminary research, prototyping phase, dan assessment phase. Partisipan dalam penelitian ini, yaitu pakar, siswa SD, dan guru SD. Data diperoleh dengan melakukan triangulasi data dan dianalisis dengan pengolahan data kuantitatif deskriptif. Temuan penelitian menunjukkan bahwa profil karakteristik siswa cenderung kesulitan dalam menulis karangan prosa. Profil analisis kebutuhan menunjukkan bahwa siswa SD sangat menyukai cerita dongeng fantasi, fabel, parabel, mite, dongeng realistis, dan sage. Prototipe bahan ajar literasi menulis prosa yang valid sesuai dengan kebutuhan siswa.
\end{abstract}

Kata Kunci: karakter positif, literasi menulis, sekolah dasar.

\begin{tabular}{|c|c|c|}
\hline Submitted & Accepted & Published \\
\hline 09 November 2019 & 09 Januari 2020 & 28 Januari 2020 \\
\hline
\end{tabular}

\begin{tabular}{|l|c|c|}
\hline Citation & $:$ & $\begin{array}{r}\text { Chandra., Arief, D., Kharisma, K., M. Habibi., \& Suriani, A. (2020). Writing Literacy As An Effort To Build Positive } \\
\text { Character Of Elementary School Students. Jurnal PAJAR (Pendidikan dan Pengajaran), 4(1), 99-110. DOI : } \\
\text { http://dx.doi.org/10.33578/pjr.v4i1.7863. }\end{array}$ \\
\hline
\end{tabular}

\section{PENDAHULUAN}

Keterampilan menulis oleh para ahli pengajaran bahasa ditempatkan pada tataran paling tinggi dalam proses pemerolehan bahasa. Hal ini disebabkan keterampilan menulis merupakan keterampilan produktif yang hanya dapat diperoleh sesudah keterampilan menyimak, berbicara, dan membaca. Hal ini pula yang menyebabkan keterampilan menulis merupakan keterampilan berbahasa yang dianggap paling sulit (Cahyaningrum, Andayani, \& Saddhono, 2018). Meskipun keterampilan menulis itu sulit, tetapi peranannya dalam kehidupan manusia sangat penting sepanjang zaman (Budiyono \& Aryanti, 2016). Kegiatan menulis dapat ditemukan dalam aktivitas manusia setiap hari, seperti menulis surat, laporan, buku, artikel, dan 
sebagainya. Dapat dikatakan, bahwa kehidupan manusia hampir tidak bisa dipisahkan dari kegiatan menulis (Mumpuni \& Nurpratiwiningsih, 2017).

Menulis sangat vital dalam semua aspek pembelajaran dan kehidupan (Sylvia \& Widiati, 2017). Tanpa keterampilan menulis, siswa tidak dapat bekerja dengan efisien dan mencapai kesuksesan, baik dalam kelas maupun dalam kehidupan nyata di luar kelas. Oleh sebab itu, keterampilan menulis harus dilatihkan mulai dari $\mathrm{SD}$, sehingga siswa mampu mengungkapkan pikiran, perasaan, dan informasi secara tertulis (Habibi \& Chandra, 2018; Habibi, Chandra, Mahyuddin, \& Hendri, 2018).

Keterampilan menulis jauh lebih bermakna jika memperhatikan literasi menulis dalam pengaplikasiannya (Yasa, Suyitno, \& Pratiwi, 2016). Literasi menulis dikategorikan ke dalam tiga bentuk teks yang paling sering dijumpai siswa di sekolah dan dalam kehidupan sehari-hari, yaitu: (1) prosa narasi, teks di mana penulis menceritakan sebuah cerita, apakah fakta atau fiksi; (2) prosa ekspositori, teks di mana penulis menggambarkan, menjelaskan, atau menyampaikan informasi atau pendapat faktual; dan (3) dokumen, menampilkan informasi seperti diagram, peta, tabel, grafik, daftar, atau set instruksi (Yim \& Warschauer, 2017). Kecenderungan siswa SD mengenal teks prosa dan mampu menulisnya. Jauh akan lebih bermakna jika tulisan yang dibuat oleh siswa berupa prosa yang berasal dari kehidupan sehariharinya atau berdasarkan pengalamannya (Han, 2017).

Literasi dikembangkan melalui studi spesifik bahasa Inggris dalam segala bentuknya, memungkinkan siswa untuk memahami bagaimana bahasa Inggris bekerja dalam konteks sosial yang berbeda dan secara kritis menilai opini, fakta, dan niat penulis, dan membantu mereka untuk membuat pilihan bahasa yang semakin canggih dalam teks yang mereka tulis mereka sendiri (Taufina \& Chandra, 2017; Taufina, Chandra, \& Kharisma, 2019). Literasi didefinisikan mempengaruhi instruksi kelas, layanan masyarakat, dan peluang literasi yang ditawarkan kepada siswa dan orang dewasa dengan kebutuhan dukungan yang luas (Habibi,
Chandra, \& Azima, 2019; Muhammadi, Taufina, \& Chandra, 2018). Definisi literasi harus menjelaskan sifat dari konsep yang sesuai dengan kondisi tertentu, kontekstual, memiliki akibat yang jelas, relatif, dan terikat secara kultural. Literasi jauh lebih dari "kemampuan individu memproses informasi tertulis dalam kehidupan sehari-hari" seperti yang umumnya didefinisikan (Chandra, Mayarnimar, \& Habibi, 2018). Literasi berada di atas semua sifat sosial, budaya itu peka, dan selalu tertanam dalam situasi dan konteks tertentu (Mayarnimar \& Taufina, 2017; Nurchasanah \& H.S., 2016).

Berdasarkan observasi dengan responden melalui pengamatan dan wawancara ditemukan beberapa permasalahan. Pertama, bahan ajar yang digunakan kurang menggambarkan proses pembelajaran literasi menulis yang efektif, sehingga siswa belum mampu menyerasikan hubungan antar gagasan, dan belum mampu menyerasikan hubungan antarkalimat. Akibatnya gagasan yang disampaikan sulit dipahami. Sebagian kalimat yang disusun siswa belum efektif karena masih banyak kata-kata yang mubazir. Selain itu, kalimat yang disusun siswa terlihat belum lengkap sesuai dengan struktur yang benar yaitu subjek, predikat, dan objek. Sebagian kalimat yang disusun tidak mempunyai subjek, dan yang lain tidak mempunyai predikat.

Kedua, bahan ajar literasi menulis prosa yang digunakan di SD masih kurang membawa siswa untuk mengenal sikap yang perlu dibangun di dalam prosa yang dibuat. Sikap yang ditulis siswa bahkan bukan berasal dari pengalamannya dalam menerapkan sikap tersebut.

Ketiga, bahan ajar yang digunakan siswa sulit membuat awal cerita yang menarik, menentukan ending, dan menggarap konflik dan klimaks. Selain itu, kesalahan ejaan dan tanda baca banyak ditemukan. Permasalahan pembelajaran menulis narasi tersebut disebabkan beberapa faktor, salah satu diantaranya terbatasnya pengetahuan guru tentang menulis dan terbatasnya waktu guru membina pembelajaran menulis.

Berdasarkan permasalahan yang telah dikemukakan, perlu dilakukan penelitian pengembangan. Salah satu solusi yang dapat dilakukan untuk meningkatkan literasi menulis 
prosa siswa dalam menghasilkan inovasi dan pengembangan pencerdasan karakter di SD menuju generasi emas adalah dengan melakukan

\section{KAJIAN TEORETIS}

Strategi guided writing atau menulis terbimbing merupakan salah satu strategi pembelajaran menulis yang dapat diterapkan guru bahasa (Gibson, 2008). Strategi ini dikembangkan oleh Blake dan Spenneto yang menyatakan: guided writing adalah suatu strategi untuk mengembangkan keterampilan menulis dan menggunakan keterampilan menulis untuk meningkatkan pembelajaran. Strategi ini dapat digunakan pada hampir semua jenjang. Strategi ini merupakan kerangka intruksional untuk segala bentuk tugas mengarang yang dipilih (Lan, Hung, \& Hsu, 2011).

Strategi menulis terbimbing atau guided writing adalah suatu strategi untuk mengembangkan keterampilan menulis dan menggunakan keterampilan menulis untuk meningkatkan pengajaran. Langkah-langkah penggunaan strategi guided writing (a) Persiapan (prewriting) menyiapkan siswa untuk menemukan topik dengan membantunya memilih topik yang sesuai. Dalam hal ini guru membimbing siswa dalam memilih topik, kemudian guru membantu siswa mengembangkan daftar sumber informasi yang diperlukan untuk mengembangkan topik. (b) Penyusunan draf kasar (drafting) guru membantu siswa merumuskan pertanyaan terkait dengan

\section{METODE PENELITIAN}

Metode penelitian yang dilakukan merujuk pada model pengembangan mixed method dengan model plomp. Model plomp terdiri dari tiga tahap, yaitu: (1) analisis pendahuluan (preliminary research), (2) perancangan (prototyping phase), dan (3) penilaian (assesment stage) (Plomp \& Nieveen, 2013). Model plomp yang digunakan dapat mengetahui kebutuhan siswa pada tahap analisis pendahuluan/ preliminary research dan menghasilkan desain prototype dengan self evaluation dan expert review evaluation oleh ahli pada tahap perancangan/ prototyping phase penelitian pengembangan bahan ajar literasi menulis prosa untuk siswa kelas IV SD.

topik yang ingin dikembangkan. Dalam langkah ini, guru membantu siswa memberikan daftar pertanyaan yang ingin dijawab siswa. (c) Merevisi tulisan (revising) guru membimbing siswa untuk mengumpulkan dan mengorganisasikan ide untuk menjawab pertanyaan. Dalam hal ini, guru membantu siswa membuang informasi yang tidak terkait dengan topik yang akan dikembangkan. Kemudian siswa menulis draf pertama dengan menggunakan informasi yang sudah diperoleh dan diorganisasikan. (d) Melakukan penyuntingan (editing) masing-masing siswa diminta membacakan draf tulisannya kepada teman pasangannya untuk mendapatkan umpan balik, saran, dan komentar dari temannya. Pada saat yang bersamaan, siswa mencatat saran, umpan balik, dan komentar dari teman pasangannya untuk perbaikan tulisannya. (e) Berbagi dengan teman dan saling memeriksa tulisan (sharing) siswa menukar hasil revisinya dengan teman pasangannya. Selanjutnya, temannya mengedit hasil karangannya dengan mengidentifikasi kesalahan tata bahasa, tanda baca, dan lain-lain yang perlu diperbaiki dan siswa melanjutkan tulisannya kembali setelah direvisi (Mourssi, 2013).

berdasarkan kebutuhan. Prototype diujicoba dengan metode one to one evaluation. Hasil evaluasi dilanjutkan dengan ujicoba dengan metode small group dan fielt test evaluation untuk mengetahui praktikalitas. Sedangkan untuk mengetahui efektivitas dilakukan ujicoba dengan metode fielt test evaluation pada tahap penilaian/ assesment stage di kelas yang berbeda.

Analisis awal memfokuskan penelitian pada tahap analisis pendahuluan (preliminary research). Tahap analisis pendahuluan (preliminary research) dilakukan analisis profil kebutuhan, analisis profil kurikulum, dan 
analisisn profil karakteristik siswa di SD Negeri 06 Padang Besi Kecamatan Lubuk Kilangan. Perancangan (prototyping phase) prototipe bahan ajar literasi menulis prosa dengan menggunakan strategi guided writing untuk siswa SD dilakukan dengan bedasarkan hasil analisis pada tahan

\section{HASIL DAN PEMBAHASAN Hasil Analisis Profil Kurikulum}

Hasil analisis kurikulum menunjukkan bahwa kurikulum yang digunakan yaitu kurikulum tingkat satuan pendidikan. Fokus materi yang digunakan pada kelas IV SD keterampilan menulis.

Literasi menulis yang disajikan untuk siswa disesuaikan dengan tuntutan kurikulum keterampilan menulis sesuai dengan Kompetensi Inti (KI) dan Kompetensi Dasar (KD). Hasil dari analisis kurikulum mata pelajaran bahasa Indonesia khususnya keterampilan menulis kelas IV SD diperoleh data bahwa materi kurang sesuai dengan kompetensi literasi menulis yang harus dicapai siswa, sehingga kurikulum perlu dimodifikasi. Tindakan modifikasi dilakukan terhadap KD 8.1 Menyusun karangan tentang berbagai topik sederhana dengan memperhatikan penggunaan ejaan (huruf besar, tanda titik, tanda koma, dll.). Materi pada KD 8.1 dimodifikasi disebabkan belum sesuai dengan tuntutan literasi menulis. Hasil revisi KD yaitu menjadi KD 8.1 Menyusun karangan tentang berbagai topik sederhana dengan memperhatikan penggunaan ejaan (huruf besar, tanda titik, tanda koma, dll.) dan kaidah literasi menulis karangan.

\section{Hasil Analisis Profil Karakteristik Siswa}

Hasil analisis karakteristik siswa menunjukkan bahwa siswa mampu menggunakan struktur bahasa yang lebih kompleks. Hal ini dibuktikan pada saat siswa menyampaikan pendapatnya dalam berkelompok. Bahasa yang digunakan siswa sudah komunikatif. Ketika bercerita, lawan bicara mampu memahami kalimat yang diujarkan siswa. sebelumnya. Prototipe bahan ajar literasi menulis prosa yang sudah dirancang, dilakukan self evaluation oleh seorang guru SD yang akan menggunakan prototipe. Hasil self evaluation digunakan sebagai bahan revisi. Hasil revisi digunakan untuk bahan validasi oleh pakar.

\section{Hasil Analisis Profil Kebutuhan Siswa}

Analisis kebutuhan difokuskan pada analisis kebutuhan peserta didik terhadap bahan ajar yang digunakan dalam proses pembelajaran. Data yang dikumpulkan berkaitan dengan kesukaan siswa terhadap hobi, warna, gambar, jenis cerita, dan sikap yang ingin diceritakan.

Berdasarkan observasi yang telah dilakukan di kelas IV SD Negeri 01 Sawahan Kecamatan Padang Timur Kota Padang, dua kelas paralel, SD Adzkia kecamatan Kuranji Kota Padang dua kelas paralel, SD Negeri 46 Kuranji Kecamatan Kuranji Kota Padang dua kelas Paralel, SD Negeri 06 Padang Besi Kota Padang dua kelas paralel, dan SD Negeri 08 Padang Besi Kecamatan Lubuk Kilangan Kota Padang dua kelas paralel, bahan ajar yang dikembangan yaitu literasi menulis prosa, sehingga dibutuhkan data tentang siswa yang berkaitan dengan berbagai hal yang disukai terutama certa yang disukainya dan sikap yang ingin ia ceritakan. Sedangkan hobi, warna, dan gambar yang disukai berguna untuk disain bahan ajar yang menarik bagi siswa.

Hasil observasi data cerita kesukaan siswa menunjukkan bahwa siswa kelas IV SD kota Padang sebagian besar menyukai cerita dongang fantasi. Anak-anak usia 9-10 tahun lebih tertarik dengan cerita dengan jenis dongeng yang menghibur dan humoris. Selain itu, anak kelas IV juga cenderung menyukai cerita fabel yang mengisahkan dengan tokoh hewan. Sedangkan cerita parabel yang menokohkan gabungan peran manusia dan hewan berada diurut ketiga untuk selera anak kelas IV SD di kota Padang. Anak usia mereka masih sedikit yang menyukai dongeng realistis. Cerita mithe juga kurang peminatnya. Sedangkan yang sangat sediti peminatnya adalah cerita jenis epos. Hasil observasi dapat dilihat pada gambar 4. 


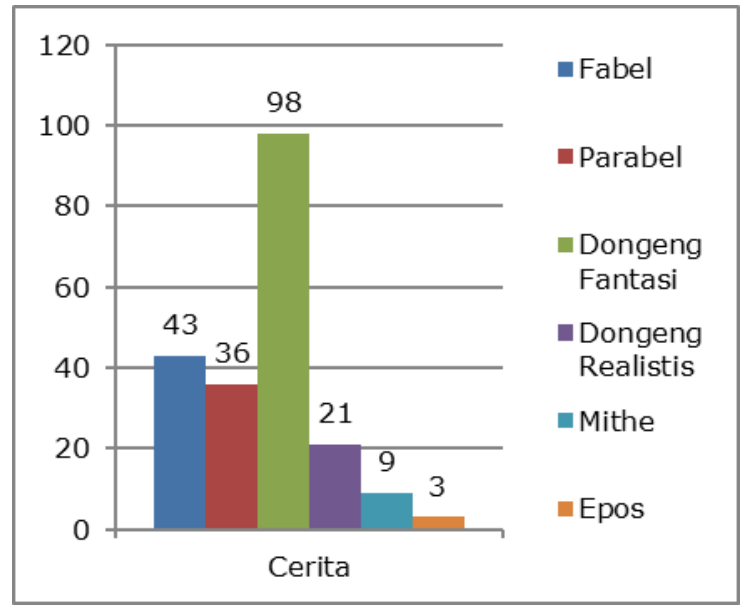

Gambar 1. Data Cerita Kesukaan Siswa Kelas IV SD Kota Padang

Hasil observasi data sikap yang ingin diceritakan siswa menunjukkan bahwa siswa kelas IV SD kota Padang sebagian besar ingin menceritakan sikap jujur. Artinya, kebiasaan siswa SD lebih menerapkan sikap jujur dalam kehidupannya. Selain sikap juur, siswa juga cenderung ingin menceritakan pengalamannya berkaitan dengan sikap menolong. Dua sikap ini sangat populer dikalangan anak-anak untuk dilaksanakan. Sikap yang paling jarang dilakukan oleh siswa SD adalah sikap berani. Sedangkan sikap sopan santun, disiplin, dan tanggung jawab berada pada batas rata-rata atau batas normal. Hasil observasi dapat dilihat pada gambar 5.

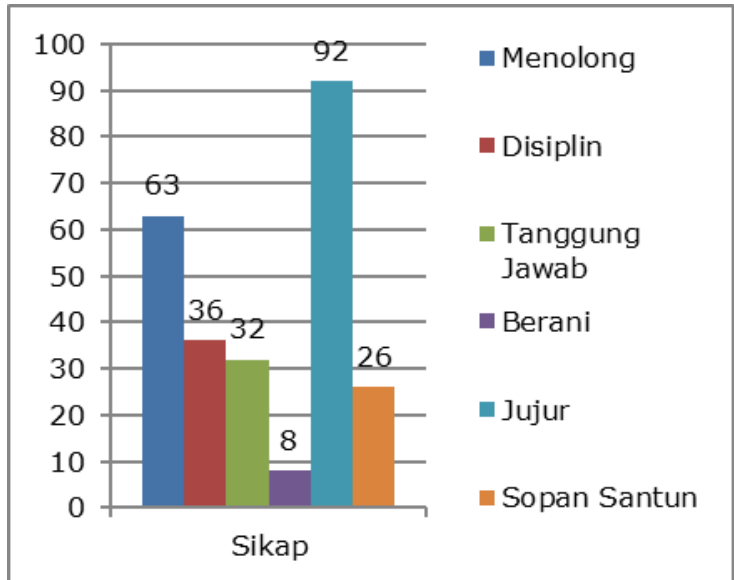

Gambar 2. Data Sikap Positif yang Pernah Dilakukan Siswa Kelas IV SD Kota Padang

\section{Hasil Rancangan Prototipe Bahan Ajar Literasi Menulis Prosa}

Hasil analisis kurikulum, analisis karakter siswa, dan hasil analisiskebutuhan siswa SD dijadikan sebagai landasan dalam pembuatan prototipe bahan ajar literasi menulis prosa dengan menggunakan strategi guided writing di SD.

Gambar yang digunakan dalam prototipe bahan ajar diperoleh dari internet. Jenis font yang digunakan dalam prototipe bahan ajar yaitu Comic Sans MS, sehingga menampilkan jenis tulisan yang lebih menarik. Ukuran huruf yang 
digunakan yaitu 12 untuk tulisan dalam cerita dan jabaran materi, 24 untuk judul subbab, dan 48 untuk cover buku. Bahan ajar disajikan dengan menggunakan warna yang lebih menarik dan dapat menarik perhatian siswa. Setiap tugas yang diberikan dibubuhi dengan beberapa ikon yang menunjukkan titik fokus pembelajaran sesuai dengan tahapan strategi guided writing yang digunakan.

Paparan materi disusun sesuai dengan urutan indikator yang ingin dicapai. Hal ini telah disesuaikan dengan komponen literasi menulis dan strategi guided writing yang digunakan. Agar lebih menarik ditambah dengan ikon-ikon tertentu sesuai dengan kegiatan yang dilakukan, yaitu: ayou mengamati contoh, ayo berkelompok, ayo mempersiapkan diri, ayo menulis, ayo memeriksa, dan ayo membacakan. Desain warna juga telah disesuaikan dengan warna hijau sebagai warna dominan disetiap halaman dan gambar orang dewasa mendampingi anak-anak menulis sebagai background.

Bagian awal dimulai dengan aktivitas mengamati contoh bacaan cerita prosa. Bahasa yang digunakan lebih disederhanakan sesuai dengan bahasa siswa SD. Setelah mengamati contoh, siswa dikenalkan dengan aturan penulisan tanda baca dalam sebuah tulisan. Selanjutnya, siswa diajak untuk mempersiapkan diri dalam menulis dengan memilih salah satu tema dalam menulis. Tema yang disediakan dalam prototipe bahan ajar literasi menulis sebanyak enam tema. Tema yang disediakan sesuai dengan jenis cerita yang akan dibuat siswa. Jika cerita yang dibuat siswa adalah cerita fabel, maka tema yang dipersiapkan adalah tema hewan. Pada pembelajaran pertama dengan jenis cerita fabel sudah disediakan pilihan tema berupa bebek, ikan, kura-kura, semut rang-rang, kupu-kupu, dan kucing.

Pembelajaran kedua, siswa dituntut membuat cerita mithe dengan pilihan tema, yaitu: rumah tua, terowongan, lobang jepang, jembatan, kendi, dan goa. Setelah menentukan tema dan membaca contoh keterangan pada tema, siswa diarahkan kepada pilihan sikap positif. Pilihan sikap positif ini berguna sebagai rujukan bagi siswa untuk memilih salah satu sikap yang akan menjadi topik pembangunan karakter di dalam cerita mereka.

Setelah siswa memperhatikan contoh, membaca aturan membuat cerita, dan memilih tema tulisannya, siswa melanjutkan kegiatan menentukan kerangka karangan yang berkaitan dengan tokoh, latar, watak, alur, klimaks cerita, dan amanat yang ingin disampaikan. Kerangka karangan dibuat dalam sebuah bagan yang didisain dengan warna yang menarik. Bagan terdiri dari beberapa lingkaran dengan warna yang berbeda.

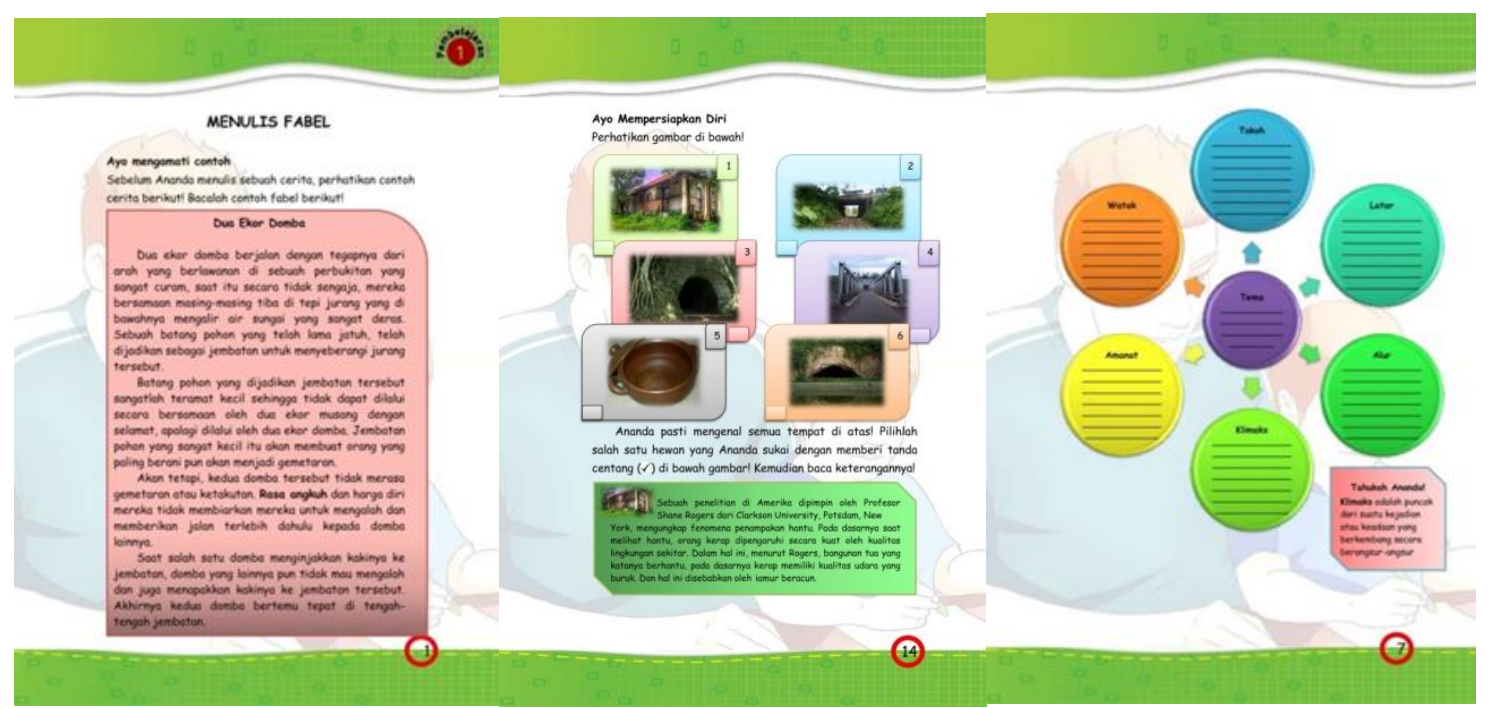

Gambar 3. Contoh Fabel, Isi Kerangka Menulis, dan Isi Prototipe Buku Menulis Prosa 
Kerangka karang bermanfaat untuk membuat cerita. Cerita yang dibuat akan direvisi dan diperbaiki. Selanjutnya cerita yang diperbaiki akan dibacakan dihadapan teman sekelas.

\section{Hasil Validasi Prototipe Bahan Ajar Menulis Prosa}

Berdasarkan hasil diskusi dan saran-saran dari validator dilakukanlah revisi terhadap bahan ajar literasi menulis prosa. Saran-saran yang diberikan oleh validator dijadikan perbaikan untuk kesempurnaan bahan ajar literasi menulis prosa. Validasi bahan ajar literasi menulis prosa dilakukan terhadap beberapa aspek yang meliputi aspek kelayakan isi, aspek kebahasaan, aspek penyajian, dan aspek kegrafikaan. Validasi aspek kelayakan isi dapat dikaji berdasarkan bahan ajar mengacu pada KI dan KD, bahan ajar sesuai dengan perkembangan siswa, bahan ajar sesuai dengan kebutuhan bahan ajar literasi menulis prosa, Kebenaran substansi materi pembelajaran dalam pembangunan karakter, bahan ajar dapat menambah wawasan siswa, dan sesuai dengan nilai-nilai moral dan sosial. Secara umum hasil validasi bahan ajar untuk aspek kelayakan isi dapat dilihat pada tabel berikut.

\section{Tabel 1. Hasil Validasi Prototipe Bahan Ajar untuk Aspek Kelayakan Isi}

\begin{tabular}{llcc}
\hline No. & \multicolumn{1}{c}{ Aspek yang Dinilai } & Rata-rata & Kategori \\
\hline 1. & Bahan ajar mengacu pada KI dan KD & 4 & Sangat Valid \\
2. & Bahan ajar sesuai dengan perkembangan siswa & 3.8 & Sangat Valid \\
3. & $\begin{array}{l}\text { Bahan ajar sesuai dengan kebutuhan bahan ajar literasi menulis } \\
\text { prosa }\end{array}$ & 3.8 & Sangat Valid \\
4. & $\begin{array}{l}\text { Kebenaran substansi materi pembelajaran dalam pembangunan } \\
\text { karakter }\end{array}$ & 3.8 & Sangat Valid \\
5. & Bahan ajar dapat menambah wawasan siswa & 4 & Sangat Valid \\
6. & Sesuai dengan nilai-nilai moral dan sosial & 3.6 & Sangat Valid \\
Rata-rata & $\mathbf{3 . 8}$ & Sangat Valid \\
\hline
\end{tabular}

Berdasarkan sajian data pada tabel 1 terlihat bahwa isi bahan ajar telah menunjukkan kesesuaian antara isi dengan $\mathrm{KI}$ dan $\mathrm{KD}$, perkembangan siswa, kebutuhan bahan ajar, kebenaran substansi materi, dan telah memberikan penambah wawasan kepada siswa dan sesuai dengan nilai moral dan sosial. Penilaian bahan ajar berikutnya ditinjau dari aspek kebahasaan. Hasil validasi dari aspek kebahasaan dapat dilihat pada tabel berikut.

Tabel 2. Hasil Validasi Prototipe Bahan Ajar untuk Aspek Kebahasaan

\begin{tabular}{llcc}
\hline No & \multicolumn{1}{c}{ Aspek yang Dinilai } & Rata-rata & Kategori \\
\hline $\mathbf{1}$ & Keterbacaan & 3.8 & Sangat Valid \\
$\mathbf{2}$ & Kejelasan informasi & 3.6 & Sangat Valid \\
$\mathbf{3}$ & Kesesuaian dengan kaidah bahasa Indonesia yang baik dan benar & 3.8 & Sangat Valid \\
$\mathbf{4}$ & Pemanfaatan bahasa secara efektif dan efisien (jelas dan singkat) & 3.4 & Valid \\
& Rata-rata & $\mathbf{3 . 6 5}$ & Sangat Valid \\
\hline
\end{tabular}

Tabel 2 menunjukkan bahwa bahasa yang digunakan pada bahan ajar telah sesuai dengan kaidah bahasa Indonesia yang baik dan benar, mudah dipahami, jelas, dan singkat. Siswa diasumsikan mampu memahami isi teks yang mereka baca. Informasi yang ada didalam prototipe dinilai mampu diserap oleh siswa. Bahasa yang digunakan sudah memanfaatkan bahasa secara efektif dan efisien (jelas dan singkat). 
Aspek selanjutnya yang dinilai pada tahap validasi bahan ajar adalah aspek penyajian. Validasi aspek penyajian dapat dikaji berdasarkan kejelasan perumusan indikator capaian, urutan sajian sistematis, bahan ajar dapat memberikan motivasi dan daya motivasi dan daya tarik, memberikan interaksi (stimulus dan respon), dan kelengkapan informasi. Hasil validasi untuk aspek ini dapat dilihat pada tabel 3.

Berdasarkan tabel 3 terlihat bahwa perumusan indikator capaian disajikan dengan kejelasan. Sajian prototipe bahan ajar sudah diurutkan secara sistematis. Bahan ajar dinilaidapat memberikan motivasi dan daya tarik terhadap siswa SD. Prototipe bahan ajar mampu memberikan interaksi (stimulus dan respon). Selain itu, prototipe bahan ajar dinilai memiliki informasi yang lengkap yang dibutuhkan oleh siswa SD. Hasil validasi dapat dilihat pada tabel 3 berikut.

Tabel 3. Hasil Validasi Prototipe Bahan Ajar untuk Aspek Penyajian

\begin{tabular}{llcc}
\hline No & Aspek yang Dinilai & Rata-rata & Kategori \\
\hline $\mathbf{1}$ & Kejelasan perumusan indikator capaian & 3.8 & Sangat Valid \\
$\mathbf{2}$ & Urutan sajian sistematis & 3.8 & Sangat Valid \\
$\mathbf{3}$ & Bahan ajar dapat memberikan motivasi dan daya tarik & 3.8 & Sangat Valid \\
$\mathbf{4}$ & Memberikan interaksi (stimulus dan respon) & 3 & Valid \\
$\mathbf{5}$ & Kelengkapan informasi & 3.4 & Valid \\
& Rata-rata & $\mathbf{3 . 5 6}$ & Valid \\
\hline
\end{tabular}

Berikutnya, aspek penilaian yang terakhir ditinjau dari aspek kegrafikaan. Validasi aspek kegrafikaan dapat dikaji berdasarkan Penggunaan font: jenis dan ukuran tulisan proporsional, lay out atau tata letak baik, ilustrasi, gambar, foto jelas dan mencantumkan sumber, dan desain tampilan menarik atau tidak monoton. Hasil validasi dari aspek ini dapat dilihat pada tabel berikut.

\section{Tabel 4. Hasil Validasi Prototipe Bahan Ajar untuk Aspek Kegrafikaan}

\begin{tabular}{llcc}
\hline No & \multicolumn{1}{c}{ Aspek yang Dinilai } & Rata-rata & Kategori \\
\hline $\mathbf{1}$ & Penggunaan font: jenis dan ukuran tulisan proporsional & 4 & Sangat Valid \\
$\mathbf{2}$ & Lay out atau tata letak baik & 3.6 & Sangat Valid \\
$\mathbf{3}$ & Ilustrasi, gambar, foto jelas dan mencantumkan sumber & 3.4 & Valid \\
$\mathbf{4}$ & Desain tampilan menarik atau tidak monoton & 3.6 & Sangat Valid \\
& Rata-rata & $\mathbf{3 . 6 5}$ & Sangat Valid \\
\hline
\end{tabular}

Sajian data pada tabel 4 menunjukkan bahwa penggunaan font jenis dan ukuran tulisan sudah proporsional. Lay out atau tata letak sudah baik. Ilustrasi, gambar, foto jelas, dan mencantumkan sumber. Desain tampilan menarik atau tidak monoton. Dengan demikian dapat disimpulkan bahwa bahan ajar yang dirancang telah mempunyai tampilan yang baik dan menarik.
Berdasarkan uraian data di atas, secara keseluruhan hasil validasi bahan ajar didapatkan nilai rata-rata skor keseluruhan pada validasi bahan ajar termasuk kepada kategori sangat valid. Jadi dapat disimpullkan bahwa bahan ajar literasi menulis prosa dengan menggunakan guided writing sebagai upaya pencerdasan karakter menuju generasi emas untuk Siswa di kelas IV sekolah dasar telah valid.

\section{Pembahasan}


menunjukkan bahwa kurikulum yang digunakan perlu direvisi sesuai dengan kebutuhan siswa dalam cakupan literasi menulis prosa terutama materi yang digunakan pada kelas IV SD keterampilan menulis. Revisi yang dilakukan sesuai dengan kaidah literasi menulis dan kebutuhan siswa.

\section{Analisis Profil Karakteristik Siswa}

Mengidentifikasi tingkah laku dan karakteristik siswa sangat perlu dilakukan untuk mengetahui kualitas perseorangan yang dapat dijadikan sebagai petunjuk dalam perencanaan pembelajaran (Desyafmi, Firman, \& Ifdil, 2016). Analisis karakteristik siswa dijadikan sebagi acuan dasar pengembangan buku ajar mata pelajaran bahasa Indonesia materi literasi menulis prosa.

Analisis karakteristik siswa menunjukkan bahwa siswa memiliki kemampuan berpikir analisis atau sudah mulai mampu berpikir kritis. Berpikir kritis yang ditunjukkan oleh siswa dalam proses pembelajaran berupa menanggapi pernyataan di dalam buku. Selain menanggapi pernyataan di dalam buku, siswa juga menanggapi pendapat temannya di dalam kelompok. Ditemukan juga peserta didik memberikan tanggapan terhadap apa yang diceritakan temannya di kelas.

Bahasa yang digunakan peserta didik sudah mulai komunikatif. Ketika bercerita, lawan bicara peserta didik mampu memahami kalimat yang diujarkan peserta didik. Kata-kata yang digunakan mampu membuat lawan bicara untuk menanggapi yang disampaikannya. Artinya, peserta didik mampu menganalisis hubunganhubungan yang sifatnya verbal yang menekankan pada penggunaan logika.

\section{Analisis Profil Kebutuhan}

Data analisis kebutuhan terhadap bahan ajar yang digunakan dalam proses pembelajaran. yang dikumpulkan berkaitan dengan kesukaan siswa terhadap hobi, warna, gambar, jenis cerita, dan sikap yang ingin diceritakan dapat diuraikan sebagai berikut.

Pertama jenis cerita, jenis cerita yang cocok digunakan di kelas IV SD yaitu cerita dongeng fantasi. Dongeng fantasi memiliki beberapa jenis, yaitu fantasi sederhana untuk pembaca anak-anak, cerita rakyat, binatang dengan kemampuan khusus, makhluk-mahkluk aneh, manusia dengan kemampuan khusus, benda ajaib, perjalanan melewati waktu dan ruang, tingkatan fantasi, dan kekuatan jahat (Ardini, 2012).

Kedua, sikap yang ingin diceritakan menjawab tuntutan teks literasi. Siswa dilatih membuat cerita yang disesuaikan dengan sikap positif tersurat dan tersirat di dalam cerita. PISA salah satu aspek literasi dikategorikan yaitu reflesi dan evaluasi dengan menggambarkan pengetahuan, ide atau sikap pada teks untuk menghubungkan informasi yang diberikan dalam teks merujuk pada kerangka konseptual dan pengalaman sendiri. PISA meneruskan bahwa yang perlu diperhatikan dalam salah satu aspek yang dimaksud sebelumnya yaitu membuat perbandingan atau hubungan antara teks dan pengetahuan dalam kehidupan sehari-hari, atau menjelaskan ciri khas dari teks dengan menggambar pada pengalaman atau sikap pribadi. Perlu dipahami bahwa teks yang digunakan harus memuat penanaman sikap yang dapat dikaitkan dengan kehidupan sehari-hari peserta didik (Thomson, Hillman, \& De Bortoli, 2013).

Perilaku yang dikembangan untuk kelas 4-6 lebih kompleks dibandingkan kelas 1-3. Perilaku yang diamati dan berkemungkinan muncul, yaitu religius, jujur, toleransi, disiplin, kerja keras, kreatif, mandiri, demokratis, rasa ingin tahu, semangat kebangsaan, cinta tanah air, menghargai prestasi, bersahabat, komunikatif, cinta damai, gemar membaca, peduli sosial, dan peduli lingkungan.

\section{Rancangan Prototipe Bahan Ajar Literasi Menulis Prosa}

Prototipe bahan ajar literasi membaca dirancang sesuai dengan perpaduan antara teori strategi guided writing dengan literasi menulis, menulis prosa serta analisis profil kebutuhan siswa. Gabungan teori dan temuan analisis profil kebutuhan siswa menghasilkan bahan ajar literasi menulis prosa. Menulis prosa diawali dengan mengamati contoh cerita yang akan dibuat. Dilanjutkan dengan menentukan tema. Tema yang dipilih digunkan untuk membuat kerangka karangan. Kerangka karangan dikembangkan menjadi sebuah cerita. Cerita yang sudah selesai direvisi dan diperbaiki semua kesalahan yang 
ditemukan. Hasil perbaikan siap untuk dipublikasikan dengan menceritakannya di hadapan teman sekelas. Pembelajaran pertaman, siswa diajak membuat cerita prosa jenis fabel. Pembelajaran kedua, siswa diarahkan untuk membuat cerita prosa jenis parabel. Pembelajaran ketiga, siswa membuat cerita prosa jenis mithe. Pertemuan keempat, siswa membuat cerita prosa jenis dongeng fantasi. Pertemuan kelima, siswa membuat cerita prosa jenis dongeng imajinatif. Pertemuan enam, siswa membuat cerita prosa jenis cerita anak.

Berkaitan dengan amanat yang ingin disampaikan oleh siswa dalam ceritanya, siswa dituntut menceritakan salah satu sikap positif yang pernah ia lakukan di dalam ceritanya. Cerita yang diangkat oleh siswa bersumber dari pengalaman yang dijadikan sebuah kisah dalam bentuk fabel, parabel, mite, dongeng, dan cerita anak.

\section{Validasi Prototipe Bahan Ajar Menulis Prosa}

Validitas prototipe bahan ajar yang telah dikembangkan dikatakan valid apabila memenuhi kriteria Plomp. Menurut (Plomp \& Nieveen, 2013) karakteristik dari produk yang dikatakan valid apabila ia merefleksikan jiwa pengetahuan (state of the art knowledge). Hal inilah yang dikatakan dengan validasi isi (content validiy). Selanjutnya, komponen-komponen produk tersebut harus konsisten satu sama lain (validitas konstruk). Oleh sebab itu, validasi yang dilakukan terhadap bahan ajar literasi menulis prosa dengan menggunakan guided writing pada penelitian ini menekankan pada validitas isi (content validity) dan validitas konstruksi (construct validity). Berdasarkan analisis data penilaian validasi dari validator, maka validitas RPP dan bahan ajar literasi menulis prosa dengan menggunakan guided writing di kelas IV yang dikembangkan tergolong sangat valid.

Validasi bahan ajar dilakukan

\section{SIMPULAN DAN REKOMENDASI}

Penelitian yang dilakukan merupakan penelitian pengembangan bahan ajar literasi menulis prosa sebagai upaya pembangunan karakter menuju generasi emas Indonesia untuk berdasarkan beberapa aspek yaitu aspek kelayakan isi, aspek kebahasaan, aspek penyajian, dan aspek kegrafikaan. Hasil validasi ditinjau dari kelayakan isi memperoleh nilai rata-rata 3,8 dengan kategori sangat valid. Ini berarti bahan ajar yang dikembangkan telah mengandung isi yang berkaitan dengan KI dan KD, materi, sesuai dengan tingkat perkembangan siswa, sesuai kebutuhan bahan ajar, dapat menambah wawasan siswa dan sesuai dengan nilai-nilai moral dan sosial.

Validasi pada aspek kebahasaan diperoleh rata-rata 3.65 yang termasuk ke dalam kategori sangat valid. Ini berarti bahasa yang digunakan pada bahan ajar telah sesuai dengan kaidah bahasa Indonesia yang baik dan benar serta mudah dipahami. Hasil diperoleh setelah dilakukan perbaikan pada bahan ajar terkait penggunaan kalimat yang efektif dan penggunaan bahasa yang disesuaikan dengan tingkat perkembangan siswa.

Ditinjau dari aspek penyajian, bahan ajar yang dikembangkan telah jelas adalam merumuskan indikator. Bahan ajar juga dapat memberikan motivasi, interaksi, dan informasi yang menarik kepada siswa. Hal ini terlihat dari hasil validasi yang telah dinyatakan valid oleh para validator yaitu dengan rata-rata 3.56 yang tergolong ke dalam kategori sangat valid.

Aspek kegrafikaan, diperoleh hasil validasi dengan rata-rata 3.65 yang termasuk ke dalam kategori sangat valid. Ini menunjukkan bahan ajar dapat terbaca dengan jelas, baik untuk tata letak, dan menggunakan gambar serta desain yang menarik. Pada awalnya menurut validator terdapat beberapa penggunaan warna yang kurang cocok atau serasi. Berdasarkan masukan dari validator, dilakukan beberapa revisi berkaitan dengan hal tersebut. Sehingga pada akhirnya didapat penyajian bahan ajar yang sangat valid berdasarkan aspek kegrafikaan.

siswa kelas IV SD. Saat ini difokuskan pada analisis penelitian tahap awal atau preliminary research. Temuan penelitian dalam analisis awal bahwa siswa kelas IV SD cenderung kesulitan 
dalam menulis karangan prosa dan belum pernah menulis prosa yang diarahkan pada penanaman karakter. Analisis kebutuhan menunjukkan bahwa siswa SD sangat menyukai cerita fabel, mite, parabel, sage, dongeng fantasi, dan dongeng realistis.

\section{DAFTAR PUSTAKA}

$$
\text { Diharapkan praktisi pendidikan }
$$

Ardini, P. P. (2012). Pengaruh Dongeng dan Komunikasi Terhadap Perkembangan Moral Anak Usia 7-8 Tahun. Jurnal Pendidikan Anak, 1(2), 44-58. Retrieved from

https://journal.uny.ac.id/index.php/jpa/articl e/view/2905

Budiyono, H., \& Aryanti, P. T. (2016). Pengaruh Penerapan Model Peta Konsep dan Penalaran Terhadap Kemampuan Menulis Esai Mahasiswa. Bahasa Dan Seni, 44(1), 86-98.

Cahyaningrum, F., Andayani, \& Saddhono, K. (2018). Peningkatan Keterampilan Menulis Argumentasi Melalui Model Think Pair Share Dan Media Audiovisual Pada Siswa Kelas X-10 SMA Negeri Kebakkramat Improving Argumentation Writing Skill Through Think Pair Share Model Using Audiovisual Media For Students X-10 G. Jurnal Pendidikan Dan Kebudayaan, 3(1), 44-55.

https://doi.org/10.24832/jpnk.v3i1.605

Chandra, Mayarnimar, \& Habibi, M. (2018). Keterampilan Membaca dan Menulis Permulaan Menggunakan Model VARK untuk Siswa Sekolah Dasar. Jurnal Inovasi Pendidikan Dan Pembelajaran Sekolah Dasar, 2(1), 72-80. https://doi.org/https://doi.org/10.24036/020 1821100050-0-00011

Desyafmi, H., Firman, F., \& Ifdil, I. (2016). Peningkatan Motivasi Siswa dalam Menyelesaikan Tugas Melalui Layanan Informasi. Konselor, 3(1), 35-41. https://doi.org/10.24036/02014313496-0-00

Gibson, S. A. (2008). Guided Writing Lessons: Second-Grade Students' Development of Strategic Behavior. Reading Horizons, 48(2), 111-132. menggunakan bahan ajar yang berisi tentang cerita tersebut dalam proses pembelajaran. Kedepannya dihasilkan bahan ajar yang sesuai dengan kebutuhan siswa, karakteristik siswa, proses menulis, dan tuntutan dalam literasi menulis prosa yang sesungguhnya.

Habibi, M., \& Chandra. (2018). Strategi Direct Writing Activity Sebagai Upaya Peningkatan Keterampilan Menulis Deskripsi Bagi Siswa Kelas Ii Sd. Jurnal Inovasi Pendidikan Dan Pembelajaran Sekolah Dasar, 2(1). Retrieved from http://e-journal.unp.ac.id/index.php/jippsd

Habibi, M., Chandra, \& Azima, N. F. (2019). Pengembangan Bahan Ajar Menulis Puisi Sebagai Upaya Mewujudkan Literasi Sastra di Sekolah Dasar. ESJ (Elementary School Journal), 9(1), 8-16. Retrieved from http://prosiding.unipma.ac.id/index.php/ISP E/article/view/1241

Habibi, M., Chandra, C., Mahyuddin, R., \& Hendri, S. (2018). Validity of Teaching Materials for Writing Poetry Based on Creative Techniques in Elementary Schools. Mimbar Sekolah Dasar, 5(3), 145. https://doi.org/10.17509/mimbarsd.v5i3.14501

Han, S. (2017). Teaching Google search techniques in an L2 academic writing context. Language Learning \& Technology, 21(3), 172-194. Retrieved from http://llt.msu.edu/issues/october2017/hanshi n.pdf

Lan, Y. F., Hung, C. L., \& Hsu, H. J. (2011). Effects of guided writing strategies on students' writing attitudes based on media richness theory. Turkish Online Journal of Educational Technology, 10(4), 148-164.

Mayarnimar, \& Taufina. (2017). Validity Analysis of the Vark ( Visual, Auditory, Read- Write , and Kinesthetic ) Model Based Basic Reading and Writing Instructional Materials for the 1St Grade. International Conference for Science Educators and Teachers, 118, 870-874.

Mourssi, A. (2013). Theoretical and practical linguistic shifting from product /guided 
writing to process writing and recently to the innovated writing process approach in teaching writing for second/foreign language learners. International Journal of Academic Research in Business and Social Sciences, 3(5), 731-751.

Muhammadi, Taufina, \& Chandra. (2018). Literasi Membaca untuk Memantapkan Sosial Siswa Sekolah Dasar. LITERA, 17(2), 202-212. https://doi.org/http://dx.doi.org/10.21831/ltr .$v 17 i 2.16830$

Mumpuni, A., \& Nurpratiwiningsih, L. (2017). The Development of A Web-Based Learning To Improveof A Creative Writing Abilityof Pgsd Students.

Nurchasanah, \& H.S., S. (2016). Perangkat Perkuliahan Pembelajaran Literasi Berbasis E-Learning. Bahasa Dan Seni, 44(2), 224240.

Plomp, \& Nieveen. (2013). An Introduction to Educational Design Research.

Sylvia, \& Widiati, U. (2017). The Effect Of Written Retelling Technique On Students, Reading Comprehension Across Personality Learning Styles. Bahasa Dan Seni, 45(1), 27-39.

Taufina, \& Chandra. (2017). Developing the Big Questions and Bookmark Organizers (BQBO) Strategy-Based Reading Literacy
Learning Materials in the 4th Grade of Elementary School. International Conference for Science Educators and Teachers, 118(5), 857-864. Retrieved from https://www.atlantis-

press.com/proceedings/icset-17/25886637

Taufina, Chandra, \& Kharisma, A. (2019). Technology integration in thematic learning to welcome the era of the industrial revolution 4.0 in elementary schools. Proceeding Internasional Seminar of Primary Education, 2, 10-19. https://doi.org/https://doi.org/10.24114/esjp gsd.v9i1.14297

Thomson, S., Hillman, K., \& De Bortoli, L. (2013). A teacher's guide to PISA reading literacy.

Yasa, I. N., Suyitno, I., \& Pratiwi, Y. (2016). Critical Reading And Writing Across The Curriculum Assisted By Metacognitive Strategy (BTS) Toward Student Study Club At Undiksha. Bahasa Dan Seni, 44(1), 32 38.

Yim, S., \& Warschauer, M. (2017). Web-Based Collaborative Writing in L2 Contexts: Methodological Insights From Text Mining. Language Learning \& Technology, 21(211), 146-165. Retrieved from http://llt.msu.edu/issues/february2017/yim warschauer.pdf 